\section{Forkortelser i vår faglitteratur}

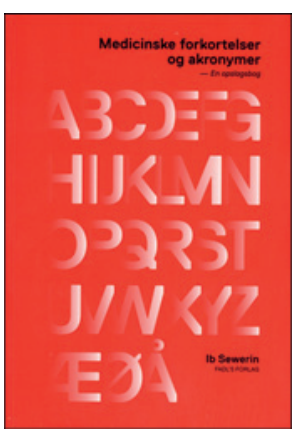

\author{
Ib Sewerin \\ Medicinske forkortelser og akronymer \\ En opslagsbog. $248 \mathrm{~s}$. København: FADL's \\ Forlag, 2012. Pris DKK 150 \\ ISBN 978-87-7749-680-6
}

Vi lever i en travel verden. Ja, så travel er den blitt at vi ikke lenger har tid til å fullføre det skrevne ord, men må ty til forkortelser. Ofte kan man stille spørsmål ved hensikten med en slik fremgangsmåte, siden forkortelsene ikke alltid blir så forståelige som man kunne ønske. De er kanskje innlysende for den indre krets som daglig omgås disse bokstavkombinasjonene, men for utenforstående kan det ofte føre til pinlige misforståelser. For eksempel for den som måtte tro at $\mathrm{MAO}$ har noe med Kinas store, forgangne leder å gjøre, når det $\mathrm{i}$ stedet viser seg å bety noe så prosaisk som monoaminoksidase - ja, med litt velvilje også «maximal acid output» (vedrørende histaminprøver). Og AA kan bety noe annet enn Anonyme Alkoholikere, nemlig «achievement age»-hvis det da ikke rett og slett er initialene til Anders Antonsen. Det er neimen ikke godt å vite.

Som leseren forstår, har undertegnede ikke ubetinget sans for den angloamerikanske tendensen til å ville forkorte alle mulige begreper. At hensikten, ifølge den danske forfatteren, er «at spare plads i en tekst» og «spare tid for den skrivende» kan muligvis forsvares dersom døgnets 24 timer ikke strekker til, men at forkortelsene også skulle «lette læsningen for læseren» betviles sterkt.

Boken er en alfabetisk oversikt over en rekke av de forkortelsene som brukes innen medisinskbiologiske fagområder, hvor man i økende grad gjør bruk av engelsk terminologi. Forfatteren skiller mellom reelle forkortelser, for eksempel f.eks., og såkalte akronymer, initialforkortelser som USA, uten at man umiddelbart ser forskjellen mellom dem.

Nå er det ikke min mening å harselere over forkortelser generelt, selv om det er fristende. Intensjonen er jo den beste: Forfatteren har innsett at den medisinske profesjonen ikke kommer utenom et hav av forkortelser i løpet av en strevsom hverdag. Boken inndeles derfor i to: Fagtermer med tilhørende forkortelser og Forkortelser/ akronymer med tilhørende betydning - i alt ca. 3000 ord. De gir faktisk en meget nyttig informasjon, i den grad man støter på forkortelser i faglitteraturen. Hvorvidt man selv trenger å forkorte faguttrykkene, blir vel opp til den enkelte å avgjøre.

Uansett hva man måtte mene om forkortelser $\mathrm{i}$ vår medisinske hverdag, er dette noe man ikke kommer utenom, dessverre, iallfall ikke i den angloamerikanske litteraturen. Denne boken - i paperbackformat - kan i så måte vise seg å bli et velkomment oppslagsverk for både leger og medisinstudenter.

\section{Per Holck}

Anatomisk avdeling

Institutt for medisinske basalfag

Universitetet i Oslo

\section{God svensk grunnbok om rus og avhengighetsmedisin}

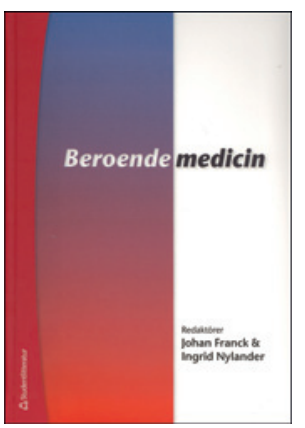

Johan Franck, Ingrid Nylander, red.

Beroendemedicin

347 s, tab, ill. Lund: Studentlitteratur, 2011.

Pris SEK 419

ISBN 978-91-44-04829-1

Denne nye svenske boken fyller et hull i vår nordiske medisinske litteratur gjennom å være den første medisinsk vinklede grunnboken innen rus og avhengighetsmedisin. Gjennom 28 tematiske kapitler skrevet av 23 sentrale svenske rusmiddelforskere og -klinikere, i tillegg til de to redaktørene, får vi en grunnleggende innføring i de sentrale områdene innen dette fagfeltet som har en lengre fartstid i Sverige enn i Norge. Norske bøker på dette området har hatt et samfunnsvitenskapelig eller psykologisk utgangspunkt, men disse forfatterne velger en medisinsk vinkling. Det betyr ikke at de har en konfronterende linje overfor andre tilnærminger, men at de i sin grunnholdning er biopsykososialt innrettet og at de dekker spesifikke medisinske temaer som behandling av komplikasjoner ved avhengighet og medikamentell behandling. Boken er derfor godt egnet til for eksempel medisin-, sykepleie- eller farmasiutdanningene, men kan også brukes innen utdanninger i psykologi eller i en master innen rus på høyskole eller universitet. Den er imidlertid for knapp til å være en fyllestgjørende behandlingsveileder, også for medisinere, som må henvises til mer omfattende bøker.

Med 25 ulike bidragsytere må det, selv med omfattende redigering, bli et sprik mellom kapitlene. Utformingen av kapitlene varierer. Noen ganger oppstår det hull i temaene, mens andre ganger overlapper kapitlene, og det blir gjentakelser. Av plassmessige hensyn har redaktørene bevisst valgt å holde visse temaer, som tvangsbehandling, promillekjøring og kriminalitet, utenfor. Det kan være riktige valg for å holde volumet nede. Epidemiologi er også nokså overfladisk beskrevet, og antall referanser er begrenset. Det er imidlertid et relativt godt stikkordregister. Forlagets intensjon er at det skal komme oppdateringer og utvidelser på nettet etter hvert, www.studentlitteratur.se/beroendemedicin.

Jeg har ikke noe problem med å anbefale boken for tidsskriftets lesere, men den som jobber med rus og avhengighet til daglig, bør ha andre bøker tilgjengelig i tillegg, for eksempel behandlingsboken fra Bergensklinikkene (1).

\section{Jørgen G. Bramness}

Senter for rus og avhengighetsforskning (SERAF) Universitetet i Oslo

1. Lossius K. red. Håndbok i rusbehandling. Til pasienter med moderat til alvorlig rusmiddelavhengighet. Oslo: Gyldendal Akademisk, 2011.
} 